Artykuly 



\section{O Piotrze Artomiuszu, pastorze kościoła NMP w Toruniu i jego twórczości}

Słowa klucze: historia Torunia, reformacja w Polsce, Piotr Artomiusz - kaznodzieja toruński

Twórczość Piotra Artomiusza (Krzesichleba) (1558-1609) wzbudzała i wzbudza zainteresowanie zarówno teologów, jak i historyków Kościoła, historyków literatury, językoznawców i w nie mniejszym stopniu muzykologów. Pomnikowe dzieło Artomiusza - Kancjonał było przedmiotem dwóch cennych artykułów śp. prof. Teresy Friedelówny ${ }^{1}$. Z kolei jej uczennica dr Joanna Kamper-Warejko poświęciła pieśniom pasyjnym i wielkanocnym w Kancjonale Piotra Artomiusza swoją dysertację doktorską ${ }^{2}$. Także w księdze dedykowanej Teresie Friedelównie w 50-lecie jej pracy naukowej znalazł się artykuł prof. Marii Karpluk, w którym autorka spróbowała wyjaśnić, skąd wzięły się nazwiska „Krzesichleb” i „Artomiusz”3. Te przytoczone wyżej fakty zadecydowały o wyborze przeze mnie tematu na konferencję poświęconą pamięci prof. Teresy Friedelówny. Zadanie swoje ograniczyłem do próby znalezienia odpowiedzi na dwa pytania: 1. Czy biogram Artomiusza znany nam w dotychczasowej literaturze jest nadal aktualny, czy wyma-

1 Teresa Friedelówna 1996: 69-78; 1993: 9-16.

2 Joanna Kamper-Warejko 2006; por. Kamper-Warejko 1998: 70-78; 2007: 81-89.

3 Maria Karpluk 2007: 92-98. 
ga korekt i uzupełnień?, 2. A jeśli taki zabieg jest konieczny, to czy może on zmienić nasze spojrzenie na twórczość Artomiusza, zwłaszcza na jego Kancjonał? Wyprzedzając dalsze nasze rozważania, czy uznanie Artomiusza za kalwinistę, a nie luteranina, miałoby wpływ na dobór pieśni w jego Kancjonale, spróbujmy odtworzyć życiorys Artomiusza w oparciu o zachowane źródła rękopiśmienne oraz dawniejsze i najnowsze edycje źródłowe i opracowania. Podstawowy materiał do biogramu Artomiusza dostarczają trzy teksty: unikatowy starodruk zachowany w zbiorach Biblioteki Uniwersyteckiej we Wrocławiu, zawierający kazanie Marcina Trisnera wygłoszone na pogrzebie Piotra Artomiusza w dniu 4 sierpnia 1609 r. w Toruniu ${ }^{4}$, rękopiśmienna prezbiteriologia pastorów ewangelickich w kościołach Najświętszej Marii Panny i św. Jerzego w Toruniu pióra E. Praetoriusa ${ }^{5}$ z r. 1710, przechowywana w zbiorach Książnicy Kopernikańskiej, oraz praca Efraima Oloffa o historii polskich pieśni religijnych opublikowana w r. $1744^{6}$. Życiorys Artomiusza doczekał się wnikliwego biogramu pióra wybitnej znawczyni polskiej Reformacji Marii Sipayłówny, opublikowanego w „Polskim Słowniku Biograficznym” w r. 19357. Autorka uważała go za luteranina. Z kolei Stanisław Salmonowicz $^{8}$ w biogramie opublikowanym w r. 1982 wskazywał, że autor historii Kościoła Ewangelickiego w Prusach - Krzysztof Hartknoch posądzał Artomiusza o kryptokalwinizm. Autorom tym nie był znany artykuł Paula Arndta $^{9}$ z r. 1939, w którym autor zgromadził poważne argumenty wskazujące na to, iż Artomiusz był jednak kalwinistą. Znajdą się one w dalszym toku wywodów. Od czasu opublikowania biogramów Artomiusza przez wymienionych autorów pojawiły się nowe edycje źródłowe i opracowania, które pozwalają na wspomniane wyżej korekty i uzupełnienia w interesującym nas życiorysie. Przede wszystkim należy wymienić dwa tomy - t. 3 (Mało-

${ }^{4}$ Leichenpredigt auss dem 25. Capitel S. Matthei von den Centnern, welche der Herrn seinen Dienern aussgethan. Gehalten den 4 Augusti 1609 Jahres, bey dem Begrebniss des Ehrwirdigen und Wohlgebohren Herrn Petri Artomii gewesenen Polnischen Predigers in den Königlichen Stadt Thorun in Preussen durch Martinum Trisnerum der Christlichen Gemein daselbs Prediger ... Thorun Gederuckt durch Augustin Ferber 1609, Biblioteka Uniwersytecka Wrocław Syg. 523595.

5 Efraim Praetorius, Presbyteriologia Thorunensis, s. 51- 51v.

${ }^{6}$ Efraim Oloff 1744 (reprint Leipzig 1976), s. 9 i n.

7 Por. Sipayłówna 1935: 168-169.

8 Por. Salmonowicz 1982: 45-49.

9 Por. Arndt 1939: 3-5; 1974: 20. 
polska) i t. 4 (Wielkopolska) „Aktów synodów różnowierczych” w opracowaniu Marii Sipayłło $(1983,1997)^{10}$, gdzie znajdujemy informacje o udziale Artomiusza w synodach głównie małopolskich. W dalszym ciągu Wydawczyni podtrzymuje swoje dawniej wyrażone zdanie, iż Artomiusz był pastorem i pisarzem luterańskim (zob. indeksy do tych tomów). W załączonych bibliografiach do obydwu tomów brak w dalszym ciągu pracy Paula Arndta.

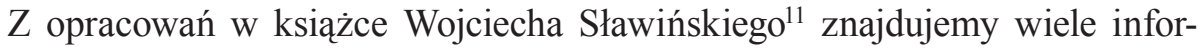
macji o wygłoszonym przez Artomiusza kazaniu i jego udziale w pracach synodu luteran, kalwinistów i braci czeskich w Toruniu w r. 1595. Niezwykle cenna jest praca niemieckiego badacza Michaela G. Müllera ${ }^{12}$ o drugiej Reformacji w Gdańsku, Toruniu i Elblągu, gdzie postać Artomiusza znalazła nowe oświetlenie.

Piotr Artomiusz urodził się 26 lipca w Grodzisku koło Poznania. Jego ojcem był zapewne Łukasz, notowany w aktach tego miasta w roku 1550 jako „Kryszychleb” i ławnik, a w roku 1555 jako rajca ${ }^{13}$. Maria Sipayłłówna (1935: 168) pisze, że jego ojciec był podobno z zawodu szewcem, a Stanisław Salmonowicz w innym biogramie Artomiusza pisze już twierdząco, że nasz bohater ,urodził się ...jako syn Łukasza Krzesichleba, mistrza szewskiego, ławnika i rajcy w rodzinnym mieście". Autorzy tych bardzo prawdopodobnych przypuszczeń nie podają jednak, na jakich źródłach się opierają. Nazwisko Krzesichleb Piotr z czasem zmienił na Artotomius, w skrócie Artomius. W szkole w Grodzisku niewątpliwie musiał odznaczać się zdolnościami, skoro w roku 1573, mając 21 lat, został zatrudniony przez Zofię z Tęczyńskich - wdowę po hrabim Stanisławie Ostrorogu, luteraninie, kasztelanie międzyrzeckim (+1568), jako wychowawca i nauczyciel jej synów - Jana (ur. w roku 1565), przyszłego wojewodę poznańskiego, który w r. 1587 przeszedł na katolicyzm, i Mikołaja (ur. w roku 1567), przyszłego kasztelana bełskiego, który pozostał ewangelikiem (por. Wotschke 1907: 100). Dzieci Stanisława i Zofii Ostrorogów pojawiły się po 18 latach ich małżeństwa. Matka chłopców od 1563 r. związała się z kościołem Braci Czeskich, co stało się z uszczerbkiem dla luteranizmu w Wielkopolsce (Wotschke 1907: 100). Podobne zjawisko miało miejsce wśród wielu rodzin szla-

10 Por. Sipayłło (oprac.) 1983; 1997.

11 Wojciech Sławiński 2002, zob. indeks.

12 Por. Müller, 1997: 99-102; 109; 229.

13 Wotschke 1907: 100, przypis 1. 
checkich w tym regionie. Theodor Wotschke (1907: 100) tłumaczy to swego rodzaju narodowym sprzeciwem wobec luteranizmu idącego z Niemiec, jak i silnymi wpływami kalwinizmu, który był bliski konfesji Braci Czeskich. Dodajmy tutaj, że z czasem kościół ten się ,spolonizował”. Jolanta Dworzaczkowa (1995: 5-6) pisze niezwykle trafnie tak: „Tylko specjaliści wiedzą, że pod wpływem Czechów powstał w Wielkopolsce - i tylko w tej dzielnicy - jeden z polskich kościołów różnowierczych, z własną konfesją, odmienną i od luterańskiej, i od kalwińskiej. Ostatecznie polska Jednota Braci Czeskich zjednoczyła się z wyznaniem ewangelicko-reformowanym." W roku 1576 Artomiusz udał się na studia uniwersyteckie w Wittenberdze i immatrykulował się tam jako „Petrus Artotonicus Grotiscensis Polonus", wraz ze swoim bratem Szymonem, jednak dopiero 25 czerwca 1577 r. ${ }^{14}$ Po powrocie do kraju Artomiusz został ordynowany na księdza, skoro w r. 1578 objął parafię w Warszawie ${ }^{15}$. Wygłaszał kazania dla luteran warszawskich, korzystając z gościnności kalwinisty Anzelma Gostomskiego - wojewody rawskiego w jego dworze na Przedmieściu Bernardyńskim na południe od Starego Miasta ${ }^{16}$. Król Stefan Batory naglony do interwencji przez nuncjusza papieskiego Vincenta Laureo nie mógł wypędzić z miasta kaznodziei bez naruszenia spokoju publicznego. Jednak zablokowanie rozpoczętej budowy kościoła w Warszawie przez katolików przyśpieszyło odejście Artomiusza z tej parafii i już w r. 1578 zbór luterański w tym mieście wyraził zgodę na przejście Artomiusza do odległego ok. $75 \mathrm{~km}$ na wschód od Warszawy, Węgrowa na Podlasiu ${ }^{17}$. Gottfried Schramm ${ }^{18}$ thumaczy tę decyzję luteran warszawskich, w znacznej mierze niemieckiego pochodzenia, faktem, iż Artomiusz skłaniał się do obcego im wówczas kalwinizmu. Rzeczywiście Artomiusz był przecież ordynowany w Kościele Ewangelicko-Reformowanym, czyli wówczas nazywanym helweckim, kalwińskim, a nie w Kościele Augsbursko-Luterańskim. Wspominał to wydarzenie w dedyka-

14 Wotschke 1907, przypis 2.

15 Andrzej Węgierski (Adrianus Regenvolscius), Liberi quator Slavoniae reformatae, Amsterdam 1679, s. 422 (cyt. za Merczyng 1904: 1; 202, przypis), pisze tak: „Petrus Artomius...(1578) .. ad Ministerium Evangelii Mazoviae vocatus maximis cum Adversariorum odiis ac periculis singularem Dei faworem et assistentiam expertus est. Anno post tertio (1581)... Criloviam ...transit".

16 Por. rozdział pt. , Sejmy i nabożenstwa ewangelickie w Warszawie (1570-1600)”.

17 Wotschke 1927: 507-523.

18 Schramm 2010: 118. 
cji skierowanej do rady miasta Torunia w książeczce „Diaeta Duszna” opublikowanej w r. 1601 tak: „Święcenie swe (choć tam namowek y wabow było dosyć) w Kościele (czego w papiestwie wiele ich pragnęło) Reformowanym wywodząc: tam się to działo, działo się przez Superintendenta i insze sługi Boże, jeszcze i po dziś po części żywe"19. Nie wiemy jednak dokładnie gdzie i kiedy miało to miejsce ${ }^{20}$. Parafia, którą objął w Węgrowie Artomiusz była parafią luterańską. Od roku 1556 funkcjonowała tutaj parafia kalwińska, ale za sprawą Piotra z Goniądza i Marcina Krowickiego przekształciła się w parafię ariańską i przetrwała jako taka do roku $1592^{21}$. Artomiusz, mimo swoich kalwińskich poglądów, przy braku odpowiedniego kandydata mógł być cennym duszpasterzem dla luteran w Węgrowie. Rzeczywiście dzięki swojej wiedzy, jak i umiejętnościom kaznodziejskim, Artomiusz był przez nich lubiany i szanowany. Katolicy - jak pisze Paul Arndt (1939: 3), podjęli próbę pozyskania go dla swego Kościoła. Kiedy to się nie powiodło, stał się obiektem zaczepek i napaści. Zaczął obawiać się nawet o swoje życie. Ostatecznie uzyskał zgodę zwierzchników i w roku 1581 opuścił Węgrów, przechodząc na kalwińską parafię w Kryłowie nad Bugiem w ziemi chełmskiej, w posiadłości kalwińskiej rodziny Ostrorogów ${ }^{22}$. W r. 1593 Stanisław Ostroróg, kasztelan bełski założył tutaj szkołę kalwińską (por. Merczyng 1904: 183). Parafia luterańska w Węgrowie po odejściu Artomiusza - wszystko na to wskazuje - przestała funkcjonować. Odnowiono ją dopiero w roku 1650 przy wsparciu kalwina księcia Bogusława Radziwiłła ${ }^{23}$. W latach 1581-1586 Artomiusz jako proboszcz parafii kalwińskiej w Kryłowie brał aktywny udział w synodach różnowierców małopolskich. Co prawda w czasie wizytacji jego parafii w Kryłowie w dniu 24 czerwca 1582 r. przebywał w Wielkopolsce (Sipayłło (oprac.), 1983: 68), to jego obecność odnotowuje-

19 Oloff 1744: 12.

20 Alina E. z Rudzkich Janowska, (Ksiądz Piotr Artomiusz Krzesichleb proboszcz luterańskiej parafii warszawskiej w 1. 1578-1581, Warszawa 1999) sądzi, że ordynacja ta miała miejsce w Warszawie.

21 Wyszomirski 1959: 137-154.

22 Praetorius, op. cit. s. 51

${ }^{23}$ H. Merczyng (1904: 225) pisze: „Oprócz zboru helweckiego /w Węgrowie/ był tu od 1650 r. zbór augsburski, który istnieje do dziś. Wspomnianego roku książę Bogusław Radziwiłł, patron zborowy, pozwolił luteranom odprawiać swe nabożeństwa w kościele reformowanym. Zborownicy augsburscy w Warszawie byli przeważnie mieszczanie warszawscy, gdyż w Warszawie od ustąpienia księdza Artomiusza i zniszczeniu zboru w. 1581 nabożeństwo stałe ewangelickie, oprócz czasów sejmowych, ustało”. 
my na kolejnych synodach w Turobinie 13 lipca 1582 r. (Sipayłło (oprac.), 1983: 69) i 19 lipca 1583 r. (Sipayłło (oprac.), 1983: 85), a także 4 października 1585 r. w Kryłowie, gdzie został wybrany seniorem. Natomiast 13 lipca 1586 r. już jako superintendent zborów wołyńskich składał pozytywne w swej treści sprawozdanie z wizytacji w parafiach: w Beresteczku, Strzemielczu, w Warężu, Rzeplinie i w innych zborach. Pisarz w sprawozdaniu z tego synodu napisał: ,/Artomiusz/ sum cum testimonio litterarum nostrorum in ministerium do Torunia odjechał, złożywszy z siebie officium senioratus, przystojnie” (Sipayłło (oprac.), 1983: 90). Od roku 1586 do zgonu w roku 1609, a więc przez 23 lata Artomiusz był proboszczem polskich zborów luterańskich w kościołach NMP i św. Jerzego w Toruniu. Liczący 12 tys. mieszkańców Toruń, po uzyskaniu w 1558 r. od króla Zygmunta Augusta przywileju na głoszenie Ewangelii zgodnie z treścią Konfesji Augsburskiej z r. 1530 oraz udzielania Komunii pod dwoma postaciami, co prawda na okres do najbliższego sejmu lub też zebrania się Soboru Narodowego, stał się bardzo szybko miastem o zdecydowanej przewadze luteran. W czasie posługi duszpasterskiej Artomiusza w Toruniu w rękach luteran były następujące kościoły: franciszkański NMP na Starym Mieście i parafialny św. Jakuba na Nowym Mieście, a za murami kościoły św. Jerzego i św. Katarzyny. Kościół parafialny św. Janów na Starym Mieście był do roku 1596 kościołem symultannym (z prawej części korzystali katolicy, a z lewej luteranie). W rękach katolików pozostał kościół św. Mikołaja i klasztor dominikanów, kościół św. Ducha i klasztory żeńskie oraz kościół św. Wawrzyńca, także za murami miasta (Małłek 2011: 45-46). Zazwyczaj w każdej parafii było dwóch pastorów, jeden wygłaszał kazania w języku niemieckim, a drugi w języku polskim. Tym polskim kaznodzieją w kościołach NMP i św. Jerzego w Toruniu był - jak już wspominałem - Artomiusz. Fakt zatrudnienia Artomiusza w gruncie rzeczy kalwinisty w parafii luterańskiej można wytłumaczyć prokalwińskimi tendencjami wśród toruńskich ówczesnych władz, choć niechętnie ujawnianymi (Małłek 2010: 63-68). Kalwinizm uważano w niektórych kręgach za ,religię ludzi wykształconych” (Neumeyer 1971: 106). Także uznawanie w praktyce, choć nie formalnie w Toruniu zasad Zgody Sandomierskiej z roku 1570, akceptującej na zasadzie wzajemności konfesje wszystkich trzech kościołów: luterańskiego, kalwińskiego i braci czeskich uławiało takie decyzje. Pastorzy nie-luteranie byli jednak zobowiązani odprawiać nabożeństwa według liturgii luterańskiej. Tak było 
w wypadku następcy Artomiusza Jana Turnowskiego, brata czeskiego, który w kazaniach unikał głoszenia własnej doktryny religijnej i pozostawił dotychczasową liturgię, do której byli przyzwyczajeni wierni, bez zmian. Johann H. Zernecke ${ }^{24}$ dodaje, iż nie chciał on popełnić błędów „niemieckojęzycznego" pastora w kościele NMP Marcina Trisnera (zm. 1629), który choć umiarkowany luteranin (jak mawiano „filipista”, czyli zwolennik Filipa Melanchtona, w czasie kazań używał „podejrzanych słów”). Miał on powiedzieć, iż gdyby władze miejskie go upoważniły, to wprowadziłby w komunii zwyczaj praktykowany przez braci czeskich „łamania chleba” i chętnie uczyniłby to. Zbór luterański był tą deklaracją tak oburzony, iż uniemożliwił mu dalszego wygłaszania kazań. W konsekwencji władze miasta zmuszone były pozbawić go urzędu duchownego i odesłać, co prawda na honorowych warunkach, na emeryturę ${ }^{25}$. Mimo tego faktu wielu następnych polskich pastorów w kościele NMP i św. Jerzego było związanych z wyznaniem Braci Czeskich. W kościele NMP chowani byli luteranie, m.in. Anna Wazówna, kalwini, m.in. Anna z Leszczyńskich Potocka $(1615-1653)^{26}$, która zmarła u swego brata prymasa Andrzeja Leszczyńskiego w Łowiczu, ale jako nie katoliczka nie mogła być tam pochowana, czy bracia czescy. Epitafia były w tym kościele w języku łacińskim, niemieckim i polskim. O tych ostatnich pisała Teresa Friedelówna (1999: 86-96). Okres toruński w życiu Artomiusza charakteryzował się jego wielkim zaangażowaniem w pracy duszpasterskiej, jak i pisarskiej. Artomiusz wziął aktywny udział w synodzie kościołów protestanckich Rzeczypospolitej, który zgromadził 115 uczestników i obradował od 21 do 26 sierpnia 1595 r. w Toruniu w kościele pofranciszkańskim NMP i pomieszczeniach tego klasztoru, wówczas mieszczącego luterańskie gimnazjum akademickie (Sławiński 2002: 156-157). Artomiusz był jednym z kaznodziei, którzy wygłosili kazania na tym synodzie ${ }^{27}$. Treść jego kazania omówił szczegółowo w swojej książce Wojciech Sławiński (2002: 190-191). Artomiusz w kazaniu nawiązał do Ewangelii św. Łukasza roz. 22, w. 24: „A wszczął się też spór miedzy nimi /apostołami/ o to, kto z nich ma być uważany za większego". Artomiusz chciał w kazaniu zwrócić uwagę uczestnikom synodu na niebezpieczeństwo chęci

\footnotetext{
24 J. H. Zernecke 1711: 191, 192 i 135.

25 Praetorius, op. cit., s. 13

26 Małłek 2011: 48.

27 Kazania synodowe...
} 
wywyższenia się, któremu w pewnej chwili ulegli nawet apostołowie. Był to jednoznaczny apel o zachowanie jedności wśród protestantów, a tym samym potwierdzenie zasad Zgody Sandomierskiej. Artomiusz także w czasie dyskusji na synodzie potwierdził swoje stanowisko. Kiedy pastor luterański z Poznania, Paweł Gericke oponował przeciwko potwierdzeniu Zgody Sandomierskiej przez synod, Artomiusz przekonywał go, iż w „Zgodzie Sandomierskiej" wiele zaczerpnięto z Konfesji Augsburskiej, natomiast nie ma wzmianki o nauce Kalwina ${ }^{28}$. Dodajmy tutaj, że zasadniczy spór dotyczył odmiennej interpretacji nauki o Komunii Świętej. Kalwiniści odmiennie niż luteranie uważali i uważają, iż w Komunii Świętej nie otrzymują prawdziwego ciała i krwi Chrystusowej, gdyż chleb „oznacza” tylko ciało Pańskie, a wino „oznacza” tylko krew Pańską ${ }^{29}$. W kazaniu synodalnym Artomiusza znalazł się także apel o posyłanie młodzieży do szkół protestanckich, a nie jezuickich, w którym mówił: „nauczą zbory palić” (Sławiński 2002: 178). Pastorzy toruńscy uczestniczący w synodzie nie uzyskali zgody władz miejskich Torunia (niemieckojęzyczny - Marcin Trisner i polskojęzyczny Piotr Artomiusz) na podpisanie dokumentów synodalnych, co oznaczałoby przystąpienie do kanonów Zgody Sandomierskiej ${ }^{30}$. Interesujące jest to, iż w protokole przy luterańskich uczestnikach synodu (Erazm Gliczner, Paweł Gericke) podaje się, jaką konfesję reprezentują. Mimo że Artomiusz był pastorem parafii luterańskiej, to informacji o jego przynależności konfesyjnej w protokołach brak. Przyznać jednak trzeba, iż kiedy zagrożono luteraninowi Pawłowi Gerickowi ekskomuniką, z powodu uporczywego odmawiania przystąpienia do Zgody Sandomierskiej, to Artomiusz próbował go bronić, podkreślając iż taka kara jest ostatecznością (Sławiński 2002: 266). W literaturze fakt niepodpisania uchwał synodu toruńskiego przez Artomiusza, a także przez obserwatorów świeckich na synodzie z Torunia, Gdańska i Elbląga, tłumaczy się obawą przed niełaską królewską, zwłaszcza że Zygmunt III wysyłał do władz miasta Torunia upomnienie w związku z udzie-

28 Sipayło (oprac.) 1983: 138; Sławiński 2002: 253.

${ }^{29}$ Maty katechizm..., s. 172.

30 Praetorius, op. cit., s. 13: "Er /Martin Trisner/ hilte ers mit den Consensu Sendomiriensis. Er war zwar allerdings der Augsburgische Confession zu gethan, doch eben wie Petrus Artomius .Er dorffte aber gleichwol solchen Consensui nicht mit unterschreiben...". W. Sławiński (2002: 305) mimo tej informacji nie notuje Marcina Trisnera wśród uczestników synodu. 
leniem gościny synodowi protestantów. Miastu groziło poza tym niebezpieczeństwo utraty kościoła św. Janów, co stało się w roku 1596 (Glemma 1934: 89). Prusacy usprawiedliwiali niepodpisanie uchwał synodu swoim przywiązaniem do luteranizmu i Konfesji Augsburskiej (Glemma 1934: 289; 305). Wydaje się, że powód był inny, chyba ważniejszy. Wielkie miasta pruskie, mimo iż solidaryzowały się z protestantami w Koronie i na Litwie, to obawiały się, że formalne przystąpienie do Zgody Sandomierskiej może osłabić ich argumentację w walce o utrzymanie choćby ograniczonej autonomii Prus Królewskich. Kolejnym ważnym faktem w życiorysie Artomiusza było powołanie go w r. 1605 do Urzędu Zborowego w Toruniu, nadzorującego życie kościelne i religijne zarówno w samym mieście, jak i w jego patrimonium. Skład tego gremium był następujący: Henryk Stroband burmistrz sympatyzujący z kalwinizmem, rajcy: Ignacy Schultz i Jerzy Naisser, oraz pastorzy: Marcin Trisner senior (superintedent), Konrad Graser kaznodzieja niemiecki i Piotr Artomiusz - kaznodzieja polski ${ }^{31}$. Artomiusz zakończył życie w wieku 57 lat, osierocając 4 synów i 5 córek. Szóstego sierpnia 1609 r. około godziny 6 rano, udając się do kościoła NMP w celu odprawienia porannego nabożeństwa, u progu swego domu doznał udaru i po 5 godzinach zakończył życie (Arndt 1939: 4). W czasie pogrzebu kazanie, w oparciu o Ewangelię św. Mateusza roz. 25, w. 14-30, wygłosił jego kolega Marcin Trisner, umiarkowany luteranin ${ }^{32}$. W tym kazaniu znalazły się słowa, iż „Artomiusz, jeśli na kazalnicy gorliwie roztrząsał obce sporne artykuły to czynił to dla umocnienia zboru chrześcijańskiego, w służbie dobru" ${ }^{33}$. Paul Arndt ${ }^{34}$ opatruje tę wypowiedź komentarzem, iż Artomiusz nigdy nie wyparł się swojego reformowanego wyznania. Pewne wątpliwości budzi ta konstatacja w świetle protokołu konwokacji seniorów w Gołuchowie z 2 stycznia 1599 r. Jest tam taki zapis ${ }^{35}$ : „Zatem ksiądz Daniel Mikołajewski przyjechawszy z Radziejowa te rzeczy proponowal: 1/ O księżej Pie-

31 Glemma 1934: 72; Małłek 2011: 50-51.

32 M. E. Trisner, Leichtpredigt ...Thorun 1609; E. Praetorius, op. cit., s. 50-51v.

33 P. Arndt (1939: 4) cytuje fragment kazania pastora Trisnera, który wygłosił je w języku niemieckim. Pełny tekst tego kazania oraz liczne epigramy-nekrologi poświęcone pamięci Artomiusza, autorstwa jego kolegów, znajdują się w starodruku przechowywanym w Bibliotece Uniwersyteckiej we Wrocławiu, zob. przypis 4.

34 Arndt 1939: 4, s. 4: „Artomius doch nie seine reformierten Glauben verleugnet”.

35 Sipayło (oprac.), 1997: 156. 
trzech $^{36}$ Augustanae Confessionis, Dresnensis et Artomio w Toruniu, którzy przeciwko Konsensowi nas hydzą, reiecta res na pogrzeb do Łabiszyna, gdzie nadzieja, że się z nimi ujrzymy, tam ich napomnieć. A zatem cum patronis et cum Toroniensibus pro occasione konferować. Vitia ich a gwałcenie Konsensu pokazując, operam patronorum rekwirować w inhibowaniu tych zgorszeń". Co prawda przy Artomiuszu nie podano jego konfesji, co uczyniono wobec ks. Piotra (Dambrowskiego) luteranina, jednak stwierdzono, iż obydwaj pastorzy kontestują Zgodę Sandomierską, co było charakterystyczne dla luteran, a nie kalwinistów. Nie można też wykluczyć, iż między seniorem dystryktu kujawskiego Danielem Mikołajewskim, sprawującym ten urząd od r. 1597, a pastorami Dambrowskim i Artomiuszem miały miejsce osobiste animozje, natomiast stosunek do Zgody Sandomierskiej był tylko pretekstem. W świetle dostępnych źródeł nie da się tego rozwikłać. Wracając do pochówku Artomiusza. Otóż został on pochowany w części północnej prezbiterium kościoła $\mathrm{NMP}^{37}$. Płyta nagrobna Artomiusza z tekstem w języku łacińskim była trzecią od strony zakrystii i istniała jeszcze w XIX w. ${ }^{38}$ Osobnego omówienia wymagałaby wszechstronna twórczość Artomiusza. Sporo na tym polu już zrobiono zwłaszcza w zakresie analizy językoznawczej czy muzykologicznej. Tutaj na potrzeby tego artykułu ograniczę się do wyliczenia jego prac. Zacznijmy od opublikowanych przez niego kazań. I tak 30 sierpnia 1582 jeszcze w Kryłowie Artomiusz dedykował Mikołajowi Ostrorogowi ,panu patronowi mojemu miłościwemu” „Kazanie pogrzebowe" poświęcone zmarłym w dniu 27 kwietnia 1582 r. hrabiemu Janowi Ostrorogowi, podczaszemu koronnemu i staroście stenrzyckiemu (kuzynowi wychowanków Artomiusza, Jana i Mikołaja Ostrorogów) i jego małżonce Halszce z Olszowca Świerczównej. Tekst ten ukazał się drukiem w rok później w Toruniu ${ }^{39}$. W r. 1588 także w Toruniu ogłosił drukiem „Kazania bądź Nauki krześcijańskie o personie Syna Bożego" (Estreicher 1891: 243/1), następnie „Homilia albo Kazanie pogrzebne nad ciałem... /Marcina

36 Piotr Dambrowski, proboszcz parafii luterańskiej w Drząznie (Dresna).

37 Semrau 1892; i Heuer 1907: 147.

38 Napis na nagrobku miał taką treść: „Boni et summi pastoris Jesu Christi fidelis servus Petrus Artomius spe magne illius ressurectionis in qua dues secundum opera unicuique retribuet quiescit sub hoc saxo quod moesti hacredes posueruntt obiit in via vocationisvers suae IV Non Sextil anno MDCIX" (Heuer 1907: 25).

39 Artomiusz 1583. 
Ostroroga z Lwówka/ 25 Januarii 1592 r. w Kurniku czynione” (Estreicher 1891: 242/2), dedykowane luteraninowi Janowi Zborowskiemu, kasztelanowi gnieźnieńskiemu. W roku 1595 opublikował w Toruniu „Sermon to iest Kazanie na dzień Wniebowzięcia" (Estreicher 1891: 243/1), dedykowane Sędziwojowi Ostrorogowi (zm. 1629) kasztelanowi międzyrzeckiemu. I kolejno w roku 1601 „Kazanie o weselu w Kanie Galilejskiej miane w Toruniu” (Estreicher 1891: 243/1) oraz w roku 1604 „O sądzie Pańskim kazanie adwentowe” i „Kazanie o ziawieniu króla w żydowstwie narodzonego” (Estreicher 1891: 243/1), obydwa teksty wydrukowane w Toruniu. Jednak szczegółowe przebadanie wszystkich kazań mogłaby rzucić nowe światło na poglądy religijne Artomiusza. Byłaby w tym bardzo pomocna analiza treści traktatu o śmierci pt. „Thanatomachia, to iest Boy ze śmiercią” (Toruń 1600) (Estreicher 1891: 243/2), dedykowanego znów Mikołajowi Ostrorogowi. Traktat wywołał ostrą polemikę z jezuitami. Osobne miejsce w twórczości Artomiusza zajmuje dziełko „Nomenclator, selectissimus rerum appelationis tribus linguis, latina, germanica, polonica explicatas indicans..." (Toruń $1601)^{40}$. Dziełko to na 116 kartkach zawierało 6000 wyrazów i zwrotów w trzech językach łacińskim, niemieckim i polskim, i miało niewątpliwie służyć przede wszystkim uczniom toruńskiego akademickiego gimnazjum. I wreszcie opus vitae Artomiusza to „Cantional albo pieśni duchowne” (Toruń 1587), który doczekał się wielu wydań w XVII w., a w XX wieku niezwykle cennego reprintu w opracowaniu niemieckiego muzykologa Güntera Kratzela ${ }^{41}$, dedykowanego pamięci luterańskiego muzyka i muzykologa z Cieszyna - Karola Hławiczki. Toruński historyk Stanisław Salmonowicz napisał o kancjonałach Artomiusza tak: „... odegrały /one/ ogromną rolę w dziejach religijnego piśmiennictwa protestanckiego w języku polskim, jak i w dziejach muzyki staropolskiej. Staranna harmonizacja pieśni i ich zapis nutowy w kancjonałach spowodowały, iż dzięki Artomiuszowi ocalało wiele staropolskich melodii religijnych. Dlatego też nie bez powodu nazywano go wielokrotnie ojcem polskiej pieśni religijnej, która szczególne warunki rozwoju w XVII w. znalazła wśród protestantów polskich w Prusach Królewskich, na Mazurach w Prusach Książęcych oraz na Śląsku"42.

40 Estreicher 1891: 243/1-2; Chojnacki 1966: 7; Tync 1928: 206-208.

41 Estreicher 1891: 242/2; Chojnacki 1966: 788; Artomiusz 1587.

42 Salmonowicz 1982: 48. 


\section{Bibliografia}

ARndT P., 1939, Die reformierten Geistlichen im Stadt-und Landkreis Thorn 1586-1921, Mitteilungen des Coppernicus-Vereins für Wissenschaft und Kunst zu Thorn, 47. Heft.

Arndt P., 1974, Artomius..., w: F. Gause, K. Forstreuter, Ch. Krollmann (Ed.), Altpreussiche Biographie, Marburg / Lahn: N. G. Elwert.

Artomiusz P., 1583, Kazanie pogrzebowe..., Toruń Książnica Kopernikańska Syg. Rkp. 190, Biblioteka Uniwersytecka w Toruniu, mikrofilm nr 1623.

Artomiusz P., 1587, Cantional albo pieśni duchowne, Thorn. Nachdruck mi ausführlichee Einleitung, herausgegeben von Günter Kratzel, Frankfurt am Main 1980.

Chojnacki W., 1966, Bibliografia polskich druków ewangelickich ziem zachodnich i pótnocnych 1530-1939, Warszawa: Wydawnictwo Zwiastun.

Dworzaczkowa J., 1995, Reformacja i kontrreformacja w Wielkopolsce, Poznań: Wydawnictwo Poznańskie.

Estreicher K., 1891, Bibliografia polska, Część III, t. 1, Kraków.

Friedelówna T., 1993, Pieśń Piotra Artomiusa w toruńskim kancjonale z 1601 r., w: K. Handke (red.), Polszczyzna regionalna Pomorza 5, s. 9-16.

FriedelównA T., 1996, Pieśni o śmierci w Toruńskim Kancjonale, w: K. Kallas (red.), Polonistyka Toruńska Uniwersytetowi w 50. rocznicę utworzenia UMK. Językoznawstwo, Toruń: Wydawnictwo UMK, s. 69-78.

FriedelównA T., 1999, Polskie napisy trumienne w toruńskim kościele Wniebowzięcia Najświętszej Maryi Panny, w: I. Sawicka (red.), Inskrypcje toruńskie, Toruń: Wydawnictwo Uniwersytetu Mikołaja Kopernika, s. 86-96.

Glemma T., 1934, Stosunki kościelne w Toruniu w stuleciu XVI i XVII, Toruń: nakł. Towarzystwa Naukowego.

Heuer R., 1907, Thorn-St. Georgen. Geschichte der Georgengemeinde..., Thorn.

KAMPER-WAREJKo J., 1998, Kilka uwag o pieśniach pasyjnych i wielkanocnych w Kancjonale Piotra Artomiusza, Acta Universitatis Nicolai Copernici. Nauki Humanistyczno-Społeczne. Filologia Polska, z. 50 (324), s. 70-78.

Kamper-Warejko J., 2006, Pieśni pasyjne i wielkonocne w Kancjonale Piotra Artomiusza (Toruń 1601), Toruń: Towarzystwo Naukowe w Toruniu.

Kamper-Warejko J., 2007, Chrystus z martwych wstał jest - wielkanocny trop w wybranych kancjonałach protestanckich, w: J Kamper-Warejko, J. Kulwicka-Kamińska, K. Nowakowska (red.), Z przeszłości i teraźniejszości języka polskiego. Księga pamiatkowa dedykowana Teresie Friedelównie, Toruń: Wydawnictwo Naukowe UMK, s. 81-89.

Karpluk M., 2007, O Piotrze Krzesichlebie Artomiuszu. Rozważania antroponimiczne, w: J. Kamper-Warejko, J. Kulwicka-Kamińska, K. Nowakowska (red.), 
Z przeszłości i teraźniejszości języka polskiego. Księga pamiatkowa dedykowana Teresie Friedelównie, Toruń: Wydawnictwo Naukowe UMK, s. 92-98.

Kazania synodowe na generalnym ewangelickim synodzie w Toruniu miesiqca Augusta roku 1595, Królewiec 1599, Biblioteka Uniwersytecka w Toruniu, Mikrofilm nr 133.

MaŁŁeK J., 2010, Henryk Stroband (1548-1609). Reformator i współtwórca gimnazjum akademickiego w Toruniu, $Z$ otchłani wieków, t. 11, s. 63-68.

MaŁŁeK J., 2011, Szkice z dziejów Kościoła Luterańskiego w Toruniu w okresie nowożytnym, w: J. Kłaczkow (red.), Ewangelicy w Toruniu (XVI-XX w.), Toruń: Wydawnictwo Adam Marszałek, s. 39-51.

Mały katechizm Marcina Lutra, 1937, objaśnił ks. Aleksander Schoeneich, Łódź.

Merczyng H., 1904, Zbory i senatorowie protestanccy w dawnej Rzeczypospolitej, Warszawa: Druk. Aleksandra Ginsa.

Müller M. G., 1997, Zweite Reformation und städtische Autonomie im Königlichen Preussen. Danzig, Elbing, und Thorn in der Epoche Konfesionalisierung (1557$-1660)$, Berlin.

Neumeyer H., 1971, Kirchengeschichte von Danzig und Westpreussen in evangelischer Sicht, Leer.

Oloff E., 1744, Polnische Liedergeschichte, Danzig (reprint Leipzig 1976).

Praetorius E., Presbyteriologia Thorunensis, Książnica Kopernikańska w Toruniu, syg. KM rkp. 129.

Salmonowicz S., 1982, Piotr Artomiusz..., w: M. Biskup (red.), Wybitni ludzie dawnego Torunia, Warszawa: PWN, s. 45-49.

Schramm G., 2010, Polska w dziejach Europy Środkowej. Studia, Poznań: Wydawnictwo Poznańskie.

Semrau A., 1892, Die Grabdenkmäler der Marienkirche in Thorn, Mitteilungen der Coppernicus Verein, Bd. VIII.

SipayŁzo M. (oprac.), 1983, Akta synodów różnowierczych w Polsce, t. 3: Małopolska 1571-1632, Warszawa: Wydawnictwo Uniwersytetu Warszawskiego.

SipayŁeo M. (oprac.), 1997, Akta synodów różnowierczych w Polsce, t. 4: Wielkopolska 1569-1632, Warszawa: Wydawnictwo Uniwersytetu Warszawskiego.

SipayŁŁówna M., 1935, Artomius (Krzesichleb) Piotr, w: W. Konopczyński (red.), Polski Stownik Biograficzny, t. 1, Kraków: Polska Akademia Umiejętności, s. $168-169$.

SŁAwIŃski W., 2002, Toruński synod generalny 1595 roku, Warszawa: Wydawnictwo Naukowe Semper.

Trisner M. E., Leichtpredigt ...Thorun 1609?

Tync S., 1928, Dzieje Gimnazjum Toruńskiego (1568-1772), t. 1, wiek XVI, Toruń: Towarzystwo Naukowe w Toruniu. 
Wотsснке Тн., 1907, Ein Schutzherr der grosspolnischen evangelischen Kirche. Zeitschrift der Historisschen Gesselschaft Posen, t. 22.

Wotschкe Th. 1927, Zur Geschichte der deutsch-lutherischen Gemeinde Węngrów, Deutsche Blätter in Polen 4, nr 10, s. 507-523.

Wyszomirski T., 1959, Z przeszłości zboru protestanckiego w Węgrowie w XVII i XVIII w., Odrodzenie i Reformacja w Polsce, t. 4, s. 137-154.

Zernecke J. H., 1711, Der Thornische Chronicke, Thorn.

\section{On Piotr Artomiusz, pastor in the Church of the Blessed Virgin Mary in Torun and his works}

( su m mary)

The biographical entry for Piotr Artomiusz, penned by Maria Sipayłłówna, published in the "Polish Biographical Dictionary" in 1935, has been so far the most complete and synthetic description of life and works of this outstanding preacher and the author of a hymn-book of unique value. M. Sipayłłówna in her biographical entry and subsequent works unwaveringly claimed that Artomiusz was a follower of Lutheranism. In the meantime new works have appeared adding new supplementary facts to his biography. As it turned out, Artomiusz leaned rather to Calvinism. Although he was a "Polish priest" in the Lutheran Church in Warsaw, Węgrów and Toruń, yet he was a Calvinist priest in Kryłów. This was possible because Polish Protestants (Lutherans, Calvinists and Czech Brothers) had been in a confessional union since 1570 on the basis of the Sandomierz accord. Artomiusz admitted that he was ordained a priest in the Evangelical-Reformed Church, which testifies to the fact that he was a Calvinist. He did not emphasize his religious preferences and in Torun he celebrated church services according to the Lutheran liturgy. It would be of great interest to examine whether Artomiusz's Calvinist views influenced both his theological (sermons) and musical (hymn-book, Torun 1587) output. In this paper the author draws attention to a monograph by Wojciech Sławiński concerned with the synod of people of other faiths held in Torun in 1595, in which Artomiusz took an active part. The sermon he preached during the synod, as well as the opinions he expressed during the debate, show that he was a fervent supporter of observing the rules accepted by Polish Protestants in Sandomierz in 1570. 